\title{
High resolution microsatellite based analysis of the mating system allows the detection of significant biparental inbreeding in Caryocar brasiliense, an endangered tropical tree species
}

\author{
ROSANE GARCIA COLLEVATTI*††, DARIO GRATTAPAGLIA†§ \\ \& JOHN DUVALL HAY \\ $\dagger$ †ós-Graduação em Biotecnologia, Universidade Católica de Brasília, SGAN 916, Mod. B, Brasília, D.F., Brasil \\ 70-970-160, \$Departamento de Ecologia, Universidade de Brasilia, Brasília, D.F., Brasil 70910-900 \\ and §Laboratório de Genética de Plantas, Recursos Genéticos e Biotecnologia - EMBRAPA,
}

C.P. 02372, Brasılia, D.F., Brasil 70770-900

\begin{abstract}
In this work we investigate the mating system of four populations of the endangered tropical tree species Caryocar brasiliense, using genetic data from 10 microsatellite loci. Eight to 10 openpollinated progeny arrays of 16 individuals, together with their mother tree, were sampled per population. Mating system parameters were estimated under the mixed mating model, implemented by the software MLTR. The single-locus outcrossing rate $\left(t_{\mathrm{s}}\right)$ varied among loci and populations, but multilocus outcrossing rates $\left(t_{\mathrm{m}}\right)$ were equal to one for all four populations. Nevertheless, biparental inbreeding $\left(t_{\mathrm{m}}-t_{\mathrm{s}}\right)$ was different from zero for all populations, indicating that outcrossing events may occur between relatives. Our results also indicate that the high polymorphism of microsatellite markers provide an extraordinary resolution to discriminate precisely selfing events from outcrossing events between close relatives. Our results indicate that, although highly outcrossed, C. brasiliense shows high levels of biparental inbreeding, most likely due to the limited flight range of pollinators and restriction in seed dispersal. Furthermore, these results suggest that Cerrado fragmentation could limit gene flow by isolating seed dispersers and territorial small sized bat pollinators inside fragments, increasing the rate of mating between close relatives. The conservation of nonisolated populations in large preserved areas may be necessary to foster outcrossing events between unrelated individuals and thus maintain species viability.
\end{abstract}

Keywords: Caryocar brasiliense, Caryocaraceae, fragmentation, mating system, microsatellites, tropical tree.

\section{Introduction}

The Brazilian Cerrado biome covers nearly $22 \%$ of the Brazilian territory $\left(2\right.$ million $\left.\mathrm{km}^{2}\right)$ consisting of a very heterogeneous vegetation. This biome displays high biodiversity, with nearly 160000 described species, including plants, animals and fungi. The number of trees and shrubs in savannah-like vegetation (cerrado sensu stricto) exceeds 800 species, nearly $40 \%$ of which are endemic (Ratter et al., 1997). Cerrado has been intensively fragmented in the last 60 years because of agricultural expansion resulting in continental islands of

*Correspondence. E-mail: rosanegc@pos.ucb.br wild habitat surrounded by an 'ocean' of crops, jeopardising species viability.

Despite the high biodiversity and endemism and the high rate of deforestation and fragmentation, studies of the reproductive biology of cerrado species are scarce (but see Gribel \& Hay, 1993; Oliveira \& Silva, 1993). Likewise, virtually no information about population genetic structure and mating system is available (but see Collevatti et al., 2001).

Caryocar brasiliense Camb. (Caryocaraceae) is a widely distributed but endangered Brazilian Cerrado tree species, locally distributed in well-delimited patches. Flowers are hermaphroditic and pollination is mainly by small sized glossophagine bats (Glossophaga soricina 
and Anoura geoffroyi) (Gribel \& Hay, 1993). The seeds are surrounded by a woody endocarp coated with a yellow fleshy mesocarp rich in oil and vitamin A, and are eaten by several wild animals, such as birds, including greater rhea (Rhea americana), macaws (Ara spp.) and parrots (Amazona spp.), pampas deer (Ozotocerus berzoarticus) and paca (Agouti paca) (Gribel \& Hay, 1993). Furthermore, C. brasiliense is a source of raw material for small and middle-sized industries, playing an important role in the economy of the inhabitants of central Brazil (Araújo, 1994). Despite its high ecological and economic importance, Cerrado fragmentation and the higher frequency of fire due to agricultural practices have affected recruitment and ultimately population size and dynamics of this species, augmented by the intense commerce in fruits (Araújo, 1994).

The mating system may determine the role of inbreeding in genetic differentiation among populations (Wright, 1940). In plants, mating system is determined mainly by: (1) reproductive system features, such as selfincompatibility mechanisms and degree of protogyny and protandry in hermaphroditic species, and plant gender in dioecious and monoecious species; (2) foraging behaviour of pollinators; (3) selective abortion by maternal regulation of seed quality or by sibling rivalry; (4) flowering phenology and individual density, which affect pollinator behaviour and, ultimately, outcrossing rate (e.g. Shaanker et al., 1988; Marshall \& Folsom, 1991).

Until the 1970s, it was believed that many tropical tree species were self-compatible, and self-pollination would predominate over cross-pollination, since conspecific individuals were highly distant from each other (e.g. Federov, 1966). High levels of inbreeding and genetic drift could lead to genetic differentiation among populations and, eventually, to speciation. Allozyme data have demonstrated, however, that tropical trees are generally highly outcrossed (e.g. O'Malley \& Bawa, 1987; Murawski \& Hamrick, 1991; Boshier et al., 1995; James et al., 1998; Loveless et al., 1998), even though some species may present significant levels of selffertilization, such as the Bombabaceae species Ceiba pentandra (Murawski \& Hamrick, 1992) and the Dipterocarpaceae species Shorea congestiflora and S. trapezifolia (Murawski et al., 1994). In addition, reproductive biology studies have shown the high frequency of dioecy and self-incompatibility in hermaphroditic species (reviewed in Bawa, 1992). Additionally, microsatellite data for Pithecellobium elegans have demonstrated that the great majority of the observed mating events resulted from long-distance gene flow (Chase et al., 1996). The same result was observed for allozyme data from other species, such as Cecropia obtusifolia (Kaufman et al., 1998) and Ficus spp. (Nason et al., 1998).

Essentially all studies of mating system of Neotropical trees have been carried out for species in tropical forests of Central America, particularly Panamá, Costa Rica and Mexico, and few studies have been published to date for Brazilian tropical species (e.g. O'Malley et al., 1988; Franceschinelli \& Bawa, 2000).

We are interested in understanding the mating system of Caryocar brasiliense, and how fragmentation, isolation and anthropic disturbance could affect it, in order to generate useful information for conservation programmes. In this work, we employ highly informative microsatellite (Simple Sequence Repeats or SSR) markers to estimate mating system parameters in four populations of $C$. brasiliense with contrasting histories of human disturbance.

\section{Materials and methods}

\section{Populations, sampling and DNA extraction}

Four populations of $C$. brasiliense with contrasting histories of human disturbance were surveyed (Fig. 1): CNV - State Park of Caldas Novas, Goiás, 12000 ha of continuous cerrado; FAL - Água Limpa Forestry Park, Brasilia - 4000 ha of cerrado surrounded by crops; PNB - Brasília National Park, Federal District, 28000 ha of continuous cerrado; URU - Uruaçú, Goiás - a cerrado fragment of 5 ha affected by the construction of the Serra da Mesa Hydroelectric Powerplant. In each of these populations, eight to 10 families of open-pollinated half-sibs were sampled in a rectangular area of $5000 \mathrm{~m}^{2}$ in FAL, $6000 \mathrm{~m}^{2}$ in CNV, $8000 \mathrm{~m}^{2}$ in PNB and $10000 \mathrm{~m}^{2}$ in URU. Although the density of reproductive individuals was low, we avoided sampling individuals at large distances. We sampled all reproductive individuals available within a radius of $100 \mathrm{~m}$ from every tree sampled. From each mother tree, expanded leaves and 16 seeds were collected and stored at $-80^{\circ} \mathrm{C}$.

Genomic DNA extraction from leaves followed the standard CTAB procedure (Doyle \& Doyle, 1987). For the progeny arrays, DNA was extracted directly from the embryo, because of the very low germination potential of dormant seeds. For DNA extraction from embryos we used the Fast DNA Kit H, and a FP120 FastPrep Cell Disruptor (BIO101/Savant Instruments Inc., CA), according to manufacturers' instructions.

\section{Microsatellite marker analysis}

Ten microsatellite loci previously developed and optimized for Caryocar brasiliense were used to genotype the mother tree and an open-pollinated progeny array of 16 

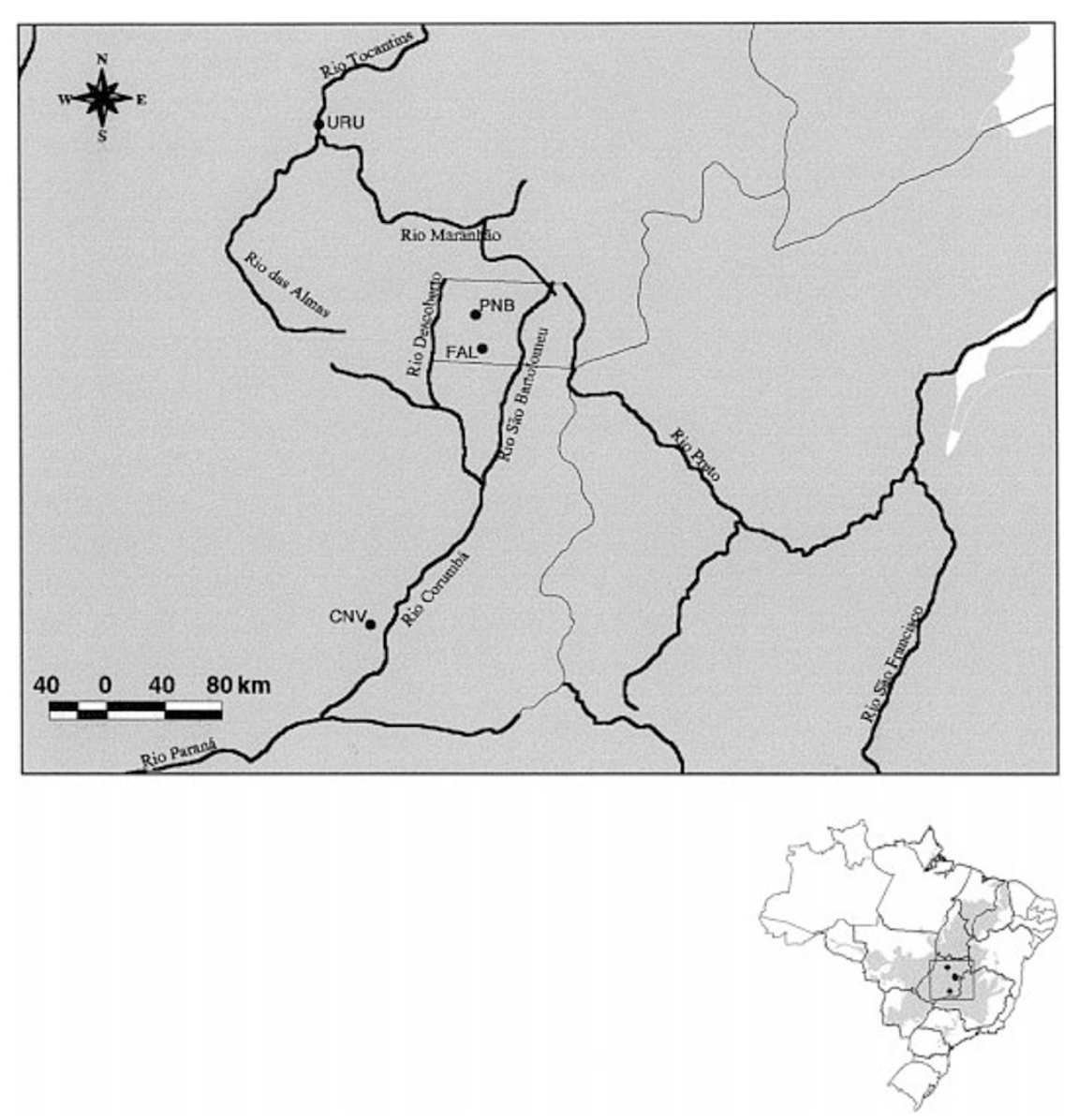

Fig. 1 Localization of the four areas in which populations of Caryocar brasiliense were surveyed. The grey area represents the Cerrado biome. Thick lines are the main rivers of the region. Thin lines are State divisions. See text for population legends. individuals. Microsatellite loci were developed from a genomic library enriched for the dinucleotide sequence motif poly AG/poly CT. Development assay, optimization and characterization of these loci have been published elsewhere (Collevatti et al., 1999).

For all genotyping experiments, microsatellite amplifications were performed in a $13 \mu \mathrm{L}$ volume containing $0.9 \mu \mathrm{M}$ of each primer, 1 unit Taq DNA polymerase (Gibco, MD), $200 \mu \mathrm{M}$ of each $\mathrm{dNTP}, 1 \times$ reaction buffer (10 mм Tris- $\mathrm{HCl}, \mathrm{pH} 8.3,50 \mathrm{~mm} \mathrm{KCl}, 1.5 \mathrm{~mm} \mathrm{MgCl}_{2}$ ), DMSO $50 \%$ and $10.0 \mathrm{ng}$ of template DNA. Amplifications were performed using a PT-100 thermal controller (MJ Research) with the following conditions: $96^{\circ} \mathrm{C}$ for $2 \mathrm{~min}(1 \mathrm{cycle}), 94^{\circ} \mathrm{C}$ for $1 \mathrm{~min}, 54$ to $56^{\circ} \mathrm{C}$ for $1 \mathrm{~min}$ (according to each primer pair annealing temperature), $72^{\circ} \mathrm{C}$ for $1 \mathrm{~min}\left(30\right.$ cycles); and $72^{\circ} \mathrm{C}$ for $7 \mathrm{~min}(1 \mathrm{cycle})$.

For genotype determination and estimation of allele sizes, the amplified products were separated on $4 \%$ denaturing polyacrylamide gels stained with silver nitrate (Bassam et al., 1991) and sized by comparison to a 10-bp DNA ladder standard (Gibco, MD) on a computer screen. Allele sizes were estimated using the software SEQAID II (Rhoads \& Roufa, 1990), taking into consideration the expected allelic series in base pairs from the primer designed and the original DNA clone from which the microsatellite locus was developed.

Inheritance of all microsatellite marker loci was confirmed by verifying the presence of one of the maternal alleles in each progeny individual.

\section{Statistical analysis}

To estimate single- and multilocus outcrossing rates (probability that each offspring of a maternal plant is an outcross), populations were analysed separately, under the mixed mating model of Ritland \& Jain (1981) and Ritland (1989), implemented by the software MLTR (Ritland, 1996).

Single- and multilocus outcrossing rates were estimated by maximum likelihood, fitting the observed proportions of genotypes descended from a known maternal genotype to the proportions expected under the mixed mating model. The mixed mating model assumes that: (1) each mating represents a random event of an outcross or a self-fertilization, with probabilities equal to $t$ and $(1-t)$, respectively; (2) no mutation and selection following fertilization may occur; (3) there is no assortative mating (the probability of an outcross is 
independent of the maternal or paternal genotypes) or variability in pollen pool frequencies (Ritland \& Jain, 1981).

As MLTR accepts only up to eight alleles, when the number of alleles exceeded eight, which occurred for all loci but $c b 1$ and $c b 13$, alleles with low frequency (under 0.05 ) were pooled into a single class. This process was performed separately in each population, since allele frequency distributions were quite different among populations (Collevatti et al., 1999).

As the maternal genotypes were known, the following parameters were estimated for each population: singlelocus $\left(t_{\mathrm{s}}\right)$ and multilocus $\left(t_{\mathrm{m}}\right)$ outcrossing rates; average single-locus inbreeding coefficient of maternal parents $(f)$; the correlation of outcrossing rate within progeny arrays or normalized variation of outcrossing rate among progeny arrays $\left(r_{\mathrm{t}}\right)$; the correlation of outcrossed paternity within progeny $\left(r_{\mathrm{p}}\right)$ or the probability that a randomly chosen pair of progeny from the same array are full sibs. Additionally, pollen and ovule allele frequencies were estimated.

The expectation-maximization method was used for maximizing the likelihood equation to estimate all parameters and correlations, and 100 bootstraps were performed and standard errors were obtained for each parameter.

To test for heterogeneity of the allele frequency distribution in the pollen pool among maternal trees in each area, contingency tables for each locus and area were constructed and a Fisher exact test was performed using a Markov chain method, implemented by the software GENEPOP (Raymond \& Rousset, 1995).

\section{Results}

In all progeny arrays, all sibs displayed at least one of the maternal alleles, confirming Mendelian inheritance and suggesting no seed contamination (Fig. 2). Loci $c b 6$ and $c b 12$ however, showed more than two alleles in the profile, suggesting locus duplication, possibly because of an ancient polyploid nature of the Caryocar genome. Nevertheless, locus interpretation of polymorphisms was not a problem as the second locus was monomorphic.

Single-locus outcrossing rate $\left(t_{\mathrm{s}}\right)$ varied among loci and populations (Table 1). For CNV, cb9 and $c b 13$ presented the lowest values of $t_{\mathrm{s}}$, but the parental inbreeding coefficient $(f)$ was positive and different from zero only for $c b 13$. For progeny arrays in FAL, $c b 13$ and $c b 23$ presented the lowest values of $t_{\mathrm{s}}$ but $f$ was higher and different from zero only for $c b 20$. For PNB and URU $c b 23$ and $c b 13$ presented the lowest values of $t_{\mathrm{S}}$ and the highest value of $f$.

Although multilocus outcrossing rates $\left(t_{\mathrm{m}}\right)$ were equal to one for all populations (i.e. $100 \%$ outcrossing), mean $t_{\mathrm{s}}$ was lower than $t_{\mathrm{m}}$ for all populations, and was highest for FAL (Table 2). Consequently, the difference $t_{\mathrm{m}}-t_{\mathrm{s}}$ (biparental inbreeding) was lower for this population, but not different among the other populations (Table 2). The parental inbreeding coefficient $(f)$ was significantly different from zero only for URU, where the density of reproductive individuals was lower (Table 2). When families were analysed, again $t_{\mathrm{m}}$ was equal to one for all half-sib families in all populations. Heterogeneity of pollen allele frequencies among maternal individuals was detected for all loci $(P<0.001$, SE $<0.001$, for all loci and populations), so violation of the mixed mating model occurred, indicating nonrandom sampling of the pollen pool by each maternal tree.

Both $r_{\mathrm{t}}$ (correlation of outcrossing rate within progeny arrays) and $r_{\mathrm{p}}$ (correlation of outcrossed paternity within progeny arrays) presented low values indicating that the outcrossing rate was independent of progeny arrays and that the probability of full-sibship within progeny arrays was very low.

\section{Discussion}

This is one of the first reports to use highly informative microsatellite markers to estimate mating system
Fig. 2 Inheritance and segregation in a open-pollinated half-sib family of Caryocar brasiliense, for locus cb20, visualized in silver-stained denaturing polyacrylamide gels. First lane is a 10-bp ladder size standard (Gibco, MD), lane 2 is the maternal tree, followed by 15 progeny individuals.

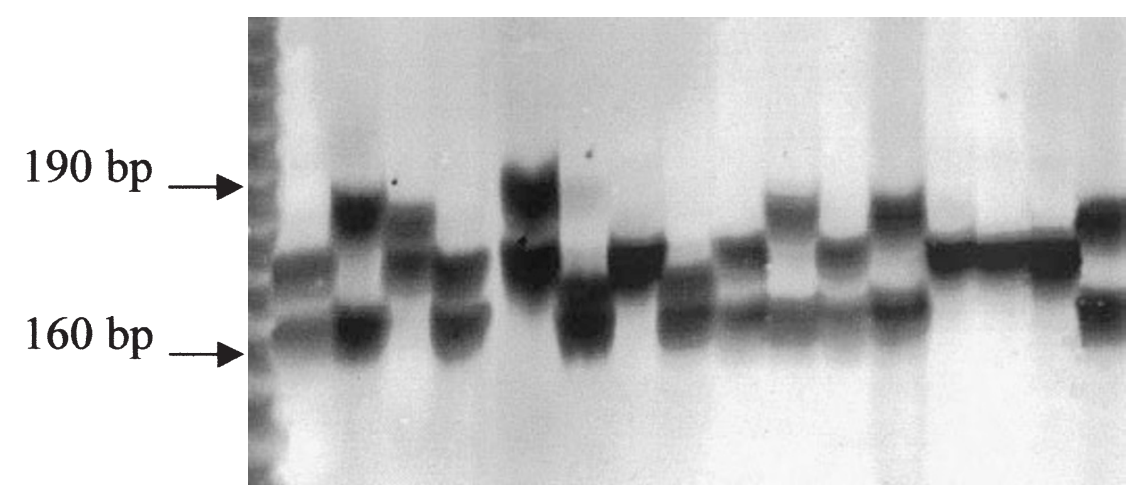

(C) The Genetics Society of Great Britain, Heredity, 86, 60-67. 
Table 1 Single-locus outcrossing rate $\left(t_{\mathrm{s}}\right)$ and maximum likelihood estimates of pollen and ovule frequency of the most common allele for four populations of Caryocar brasiliense. Pop, population; $A$, number of alleles; $f$, parental inbreeding coefficient; $N_{\mathrm{F}}$, number of families analysed; $N_{\mathrm{P}}$, number of progeny individuals

\begin{tabular}{|c|c|c|c|c|c|c|c|c|}
\hline Pop & Locus & $A$ & Pollen & Ovule & $t_{\mathrm{s}} \pm \mathrm{SE}$ & $f \pm \mathrm{SE}$ & $N_{\mathrm{F}}$ & $N_{\mathrm{P}}$ \\
\hline \multirow[t]{10}{*}{$\mathrm{CNV}$} & $c b 1$ & 8 & 0.168 & 0.381 & $0.669 \pm 0.100$ & $0.099 \pm 0.122$ & 9 & 134 \\
\hline & $c b 3$ & 8 & 0.208 & 0.364 & $0.899 \pm 0.089$ & $0.000 \pm 0.000$ & 10 & 147 \\
\hline & $c b 5$ & 8 & 0.318 & 0.286 & $0.578 \pm 0.047$ & $0.010 \pm 0.039$ & 10 & 147 \\
\hline & $c b 6$ & 8 & 0.301 & 0.286 & $0.770 \pm 0.053$ & $0.084 \pm 0.099$ & 10 & 147 \\
\hline & $c b 9$ & 8 & 0.120 & 0.286 & $0.547 \pm 0.073$ & $0.000 \pm 0.000$ & 10 & 147 \\
\hline & $c b 11$ & 8 & 0.254 & 0.182 & $0.954 \pm 0.046$ & $0.000 \pm 0.000$ & 10 & 147 \\
\hline & $c b 12$ & 8 & 0.309 & 0.150 & $0.610 \pm 0.063$ & $0.000 \pm 0.000$ & 10 & 147 \\
\hline & $c b 13$ & 6 & 0.740 & 0.792 & $0.562 \pm 0.105$ & $0.630 \pm 0.340$ & 10 & 147 \\
\hline & $c b 20$ & 8 & 0.208 & 0.304 & $0.821 \pm 0.113$ & $0.000 \pm 0.000$ & 10 & 147 \\
\hline & $c b 23$ & 8 & 0.249 & 0.182 & $0.950 \pm 0.056$ & $0.000 \pm 0.000$ & 10 & 147 \\
\hline \multirow{10}{*}{ FAL } & $c b 1$ & 8 & 0.276 & 0.333 & $0.778 \pm 0.143$ & $0.000 \pm 0.000$ & 6 & 96 \\
\hline & $c b 3$ & 8 & 0.392 & 0.278 & $0.831 \pm 0.102$ & $0.000 \pm 0.000$ & 8 & 126 \\
\hline & $c b 5$ & 8 & 0.406 & 0.294 & $0.808 \pm 0.090$ & $0.039 \pm 0.094$ & 8 & 126 \\
\hline & $c b 6$ & 8 & 0.233 & 0.294 & $0.834 \pm 0.087$ & $0.000 \pm 0.000$ & 8 & 126 \\
\hline & $c b 9$ & 8 & 0.229 & 0.188 & $0.886 \pm 0.053$ & $0.000 \pm 0.000$ & 8 & 126 \\
\hline & $c b 11$ & 8 & 0.245 & 0.222 & $0.795 \pm 0.068$ & $0.000 \pm 0.000$ & 7 & 112 \\
\hline & $c b 12$ & 8 & 0.286 & 0.235 & $0.876 \pm 0.073$ & $0.001 \pm 0.004$ & 8 & 126 \\
\hline & $c b 13$ & 8 & 0.254 & 0.211 & $0.589 \pm 0.092$ & $0.000 \pm 0.000$ & 8 & 126 \\
\hline & $c b 20$ & 8 & 0.312 & 0.278 & $0.903 \pm 0.039$ & $0.175 \pm 0.167$ & 8 & 126 \\
\hline & $c b 23$ & 8 & 0.114 & 0.444 & $0.644 \pm 0.171$ & $0.000 \pm 0.000$ & 8 & 126 \\
\hline \multirow[t]{10}{*}{ PNB } & $c b 1$ & 8 & 0.140 & 0.409 & $0.868 \pm 0.044$ & $0.050 \pm 0.113$ & 4 & 51 \\
\hline & $c b 3$ & 8 & 0.238 & 0.211 & $0.826 \pm 0.077$ & $0.000 \pm 0.000$ & 9 & 108 \\
\hline & $c b 5$ & 8 & 0.304 & 0.263 & $0.704 \pm 0.097$ & $0.087 \pm 0.087$ & 9 & 108 \\
\hline & $c b 6$ & 8 & 0.180 & 0.333 & $0.636 \pm 0.054$ & $0.000 \pm 0.000$ & 9 & 108 \\
\hline & $c b 9$ & 8 & 0.258 & 0.222 & $0.822 \pm 0.092$ & $0.000 \pm 0.000$ & 9 & 108 \\
\hline & $c b 11$ & 8 & 0.081 & 0.300 & $0.679 \pm 0.081$ & $0.112 \pm 0.143$ & 9 & 108 \\
\hline & $c b 12$ & 8 & 0.217 & 0.111 & $0.696 \pm 0.124$ & $0.005 \pm 0.007$ & 9 & 108 \\
\hline & $c b 13$ & 8 & 0.241 & 0.316 & $0.527 \pm 0.126$ & $0.116 \pm 0.127$ & 9 & 108 \\
\hline & $c b 20$ & 8 & 0.243 & 0.105 & $0.840 \pm 0.064$ & $0.000 \pm 0.000$ & 9 & 108 \\
\hline & $c b 23$ & 8 & 0.250 & 0.222 & $0.486 \pm 0.089$ & $0.190 \pm 0.141$ & 9 & 108 \\
\hline \multirow[t]{10}{*}{ URU } & $c b 1$ & 6 & 0.417 & 0.190 & $0.785 \pm 0.049$ & $0.147 \pm 0.187$ & 2 & 32 \\
\hline & $c b 3$ & 8 & 0.214 & 0.238 & $0.841 \pm 0.072$ & $0.119 \pm 0.149$ & 10 & 154 \\
\hline & $c b 5$ & 8 & 0.143 & 0.333 & $0.633 \pm 0.074$ & $0.252 \pm 0.177$ & 10 & 153 \\
\hline & $c b 6$ & 8 & 0.190 & 0.273 & $0.711 \pm 0.090$ & $0.000 \pm 0.000$ & 10 & 154 \\
\hline & $c b 9$ & 8 & 0.453 & 0.200 & $0.650 \pm 0.079$ & $0.000 \pm 0.000$ & 10 & 154 \\
\hline & $c b 11$ & 8 & 0.171 & 0.435 & $0.733 \pm 0.099$ & $0.045 \pm 0.094$ & 10 & 153 \\
\hline & $c b 12$ & 8 & 0.130 & 0.286 & $0.796 \pm 0.078$ & $0.000 \pm 0.000$ & 10 & 153 \\
\hline & $c b 13$ & 8 & 0.276 & 0.091 & $0.243 \pm 0.079$ & $0.332 \pm 0.200$ & 10 & 153 \\
\hline & $c b 20$ & 8 & 0.263 & 0.455 & $0.791 \pm 0.112$ & $0.001 \pm 0.004$ & 10 & 153 \\
\hline & $c b 23$ & 8 & 0.236 & 0.136 & $0.776 \pm 0.082$ & $0.134 \pm 0.111$ & 10 & 152 \\
\hline
\end{tabular}

parameters in a tropical tree. Although gene flow and paternity analyses have been carried out with this class of markers (e.g. Chase et al., 1996; Aldrich \& Hamrick, 1998), no study to date has explored the power of this marker class for the detailed understanding of mating systems in tropical trees. Our results indicate that the high polymorphism of microsatellite markers provides an extraordinary resolution to precisely discriminate selfing events from outcrossing events, even between close relatives. As these markers become more commonly used for this type of genetic investigation in tropical trees, complementing the popular isozymes, we should not be surprised to learn that, for some species, what had been estimated as selfing events could turn out to be more precisely interpreted as outcrossing events between relatives. Allozyme markers with limited numbers of alleles, skewed allele frequencies and expected heterozygosities in the $20-30 \%$ range may not provide 
Table 2 Multilocus outcrossing rate $\left(t_{\mathrm{m}}\right)$ and mean single-locus outcrossing rate $\left(t_{\mathrm{s}}\right)$ in four populations of Caryocar brasiliense. $f$, parental inbreeding coefficient; $r_{\mathrm{t}}$, correlation of $t$ estimates, $r_{\mathrm{p}}$, correlation of $\mathrm{p}$ estimates; $N_{\mathrm{F}}$, number of families analysed; $N_{\mathrm{r}}$, number of reproductive individuals per hectare; $N_{\mathrm{P}}$, number of progenies

\begin{tabular}{|c|c|c|c|c|}
\hline Population & $\mathrm{CNV}$ & FAL & PNB & URU \\
\hline$t_{\mathrm{m}} \pm \mathrm{SE}$ & $1.000 \pm 0.000$ & $1.000 \pm 0.000$ & $1.000 \pm 0.000$ & $1.000 \pm 0.000$ \\
\hline$t_{\mathrm{s}} \pm \mathrm{SE}$ & $0.811 \pm 0.023$ & $0.869 \pm 0.025$ & $0.771 \pm 0.029$ & $0.769 \pm 0.028$ \\
\hline$t_{\mathrm{m}}-t_{\mathrm{s}} \pm \mathrm{SE}$ & $0.189 \pm 0.023$ & $0.131 \pm 0.025$ & $0.229 \pm 0.029$ & $0.231 \pm 0.028$ \\
\hline$f \pm \mathrm{SE}$ & $0.000 \pm 0.000$ & $0.000 \pm 0.000$ & $0.006 \pm 0.006$ & $0.020 \pm 0.017$ \\
\hline$r_{\mathrm{t}} \pm \mathrm{SE}$ & $0.110 \pm 0.000$ & $0.110 \pm 0.000$ & $0.110 \pm 0.000$ & $0.110 \pm 0.000$ \\
\hline$r_{\mathrm{p}} \pm \mathrm{SE}$ & $0.205 \pm 0.042$ & $0.086 \pm 0.022$ & $0.141 \pm 0.051$ & $0.193 \pm 0.193$ \\
\hline$N_{\mathrm{F}}$ & 10 & 8 & 9 & 10 \\
\hline$N_{\mathrm{r}}$ & 16.7 & 16.0 & 11.3 & 10.0 \\
\hline$N_{\mathrm{P}}$ & 147 & 126 & 108 & 154 \\
\hline
\end{tabular}

the necessary resolution to discriminate such events in particular situations.

Low values of $r_{\mathrm{p}}$ indicate no correlation of paternal parentage, or low probability of full-sibship from the same half-sib family. Multiple paternity was expected since $C$. brasiliense is pollinated by bat species that might promote a high pollen carryover (Bawa, 1990). Additionally, abortion of ovules or initiated seeds was frequently observed - although fruits may sire four seeds, fruits with one or two developed seeds were in fact the most commonly seen. This strongly suggests early inbreeding depression leading to selective abortion, caused by nutrient limitation or by maternal regulation of seed quality or by sibling competition, or pollen limitation leading to low seed set (Shaanker et al., 1988). Further evidence of selective abortion due to inbreeding depression in $C$. brasiliense was the high rate of fruit and seed abortion observed under controlled self-pollination experiments (Gribel \& Hay, 1993).

The high multilocus outcrossing rate observed for $C$. brasiliense is comparable to values found for other tropical tree species (e.g. O’Malley \& Bawa, 1987; Murawski \& Hamrick, 1991; James et al., 1998; Loveless et al., 1998). This result suggests that this species may have an efficient self-incompatibility mechanism in place and that selective abortion may increase the outcrossing rate $\left(t_{\mathrm{m}}\right)$ by eliminating self-pollinated seeds.

Biparental inbreeding, represented by the observed difference $t_{\mathrm{m}}-t_{\mathrm{s}}$ (Ritland \& Jain, 1981), was an order of magnitude higher than values found so far for other outcrossing tropical tree species using allozyme data (e.g. James et al., 1998). The high values of $t_{\mathrm{m}}-t_{\mathrm{s}}$ (biparental inbreeding) suggest that, although outcrossing is absolute, leading to a $t_{\mathrm{m}}$ of $100 \%$, some crossfertilization events occur between close relatives. This is quite important in substructured populations where random matings occur within demes, and between closely related individuals (Ritland, 1985, 1988). In fact, $C$. brasiliense presents highly subdivided populations with $\theta$ and $\mathrm{R}_{\mathrm{ST}}$ significantly different from zero
(Collevatti et al., 2001). Nevertheless, heterogeneity of allele frequencies in the pollen pool among maternal trees was observed for all loci. This may result from matings among near-neighbour individuals. In fact, bat pollinators tend to forage in groups remaining in the same tree or group of trees for a long time (Gribel \& Hay, 1993).

Results of this study indicate that $C$. brasiliense tends to present small panmictic units or demes as a result of restriction in gene flow. Besides the fact that bats that pollinate $C$. brasiliense are small, territorial and with low flight range (Gribel \& Hay, 1993), restriction in gene flow may also be caused by limited seed dispersal. Although seeds could be dispersed by a large bird (the Great Rhea), the great majority of seeds are dispersed by gravity, keeping seeds under the mother tree canopy. In fact, we and colleagues (J.D. Hay, personal communication) have observed many seedlings under mother trees of C. brasiliense. 'Cerrado' fragmentation could also be restricting gene flow, by isolating small mammals into the fragments (Kearns et al., 1998) and thus increasing the rate of mating between closely related individuals. Furthermore, $C$. brasiliense individuals are spatially distributed in clumps and bat pollinators tend to forage inside these clumps, increasing the rate of mating between relatives. In fact, areas with lower density of reproductive individuals tended to show higher levels of biparental inbreeding.

Although a high resolution of mating events was achieved with microsatellite markers, our data did not provide clear-cut evidence of the effect of fragmentation on mating-system parameters. Fragmented areas such as URU displayed the same levels of outcrossing rate and biparental inbreeding $\left(t_{\mathrm{m}}-t_{\mathrm{s}}\right)$ as continuous areas such as CNV and PNB. We hypothesize that no pattern could be detected, mainly due to the deme structure and restricted gene flow of $C$. brasiliense, that lead to a naturally high level of biparental inbreeding. Additionally, Cerrado fragmentation is a relatively recent event ( $\sim 60$ years) in relation to the species life cycle. So, the deme structure and the rate of biparental inbreeding 
currently found may very well have existed prior to the beginning of fragmentation.

Our present results indicate, however, that fragmentation may favour the isolation among $C$. brasiliense populations, decreasing population size and increasing inbreeding, ultimately resulting in local extinction. Therefore, the maintenance of nonisolated populations in many and large preserved areas may be necessary for species viability in the Cerrado biome, providing means for gene flow by pollen and seed. Additionally, these areas play an important role in the maintenance of small populations in highly disturbed areas, as a source of pollen and seeds, and contribute to the viability of pollinator and disperser populations.

\section{Acknowledgements}

This study is part of the Doctoral Thesis of the first author, and has been supported by the Universidade de Brasília, EMBRAPA-Genetic Resources and Biotechnology, WWF (World Wildlife Fund), CNPq/PADCT (Brazilian Ministry of Science and Technology) competitive grant 62.00059/97-4 to D. G. and a fellowship to R. G. C. whose assistance we gratefully acknowledge. We wish to thank Célia M. T. Cordeiro for assistance in statistical analysis, Rosana V. Brondani for continued support in the laboratory, Kermit Ritland for authorization for the use of the MLTR software as well as Aécio A. Santos, Antônio Dimas Costa Jr., Bruno Walter, João B. Pereira, Neilton R. Oliveira, Sebastião P. Cordovil, for their kind help in field work. We also acknowledge the support of IBAMA (Brazilian Ministry of Environment) and FEMAGO (State Environmental Institute of Goiás) for authorizing plant collections in Brasília National Park and in the State Park of Caldas Novas, and the suggestions of two anonymous reviewers that helped improve this manuscript.

\section{References}

ALDRICH, P. R. AND HAMRICK, J. L. 1998. Reproductive dominance of pasture trees in a fragmented tropical forest mosaic. Science, 281, 103-105.

ARAúJo, F. D. 1994. A review of Caryocar brasiliense Camb. (Caryocaraceae) - an economically valuable species of the Central Brazilian cerrados. Econ. Bot., 49, 40-48.

BASSAM, B. J., CAETANO-ANOLLES, G. AND GRESSHOFF, P. M. 1991. Fast and sensitive silver staining of DNA in polyacrylamide gels. Analyt. Biochem., 196, 80-83.

BAWA, K. S. 1990. Plant-pollinator interactions in tropical rain forests. Ann. Rev. Ecol. Syst., 21, 399-422.

BAWA, K. S. 1992. Mating systems, genetic differentiation and speciation in tropical rain forest plants. Biotropica, 24, $250-255$.
BoShieR, D. H., CHASE, M. R. AND BAWA, K. S. 1995. Population genetics of Cordia alliodora (Boraginaceae), a Neotropical tree. 2. Mating system. Am. J. Bot., 82, 476-483.

CHASE, M. R., MOLler, C., KeSSEli, R. AND BAWA, K. S. 1996. Distant gene flow in tropical trees. Nature, 383, 398-399.

COLlEVATTI, R. G., BRONDANI, R. V. P. AND GRATTAPAGLIA, D. 1999. Development and characterization of microsatellite markers for genetic analysis of a Brazilian endangered tree species Caryocar brasiliense. Heredity, 83, 748-756.

COllevatti, R. G., GRATtApaglia, D. AND HAY, J. D. 2001. Population genetic structure of the endangered tropical tree species Caryocar brasiliense, based on variability at microsatellite loci. Mol. Ecol., 10, in press.

DOYLE, J. J. AND DOYLE, J. L. 1987. Isolation of plant DNA from fresh tissue. Focus, 12, 13-15.

FEDEROV, A. A. 1966. The structure of the tropical rain forest and speciation in the humid tropics. J. Ecol., 54, 1-11.

FRANCESCHINELLI, E. V. AND BAWA, K. S. 2000. The effect of ecological factors on the mating system of a South American shrub species (Helicteres brevispira). Heredity, 84, 116-123.

GRIBEL, R. AND HAY, J. D. 1993. Pollination ecology of Caryocar brasiliense (Caryocaraceae) in Central Brazil cerrado vegetation. J. Trop. Ecol., 9, 199-211.

JAMES, T., VEGE, S., ALDRICH, P. AND HAMRICK, J. L. 1998. Mating system of three tropical dry forest tree species. Biotropica, 30, 587-594.

KAUfMAN, S. R., SMOUSE, P. E. AND ALVAREZ-BUYLlA, E. R. 1998. Pollen-mediated gene flow and differential male reproductive success in a tropical pioneer tree, Cecropia obtusifolia Bertol. (Moraceae): a paternity analysis. Heredity, 81, 164-173.

KEARNS, C. A., INOUYE, D. W. AND WASER, N. M. 1998. Endangered mutualisms: The conservation of plant-pollinator interaction. Ann. Rev. Ecol. Syst., 29, 83-112.

LOVELESS, M. D., HAMRICK, J. L. AND FOSTER, R. B. 1998. Population structure and mating system in Tachigali versicolor, a monocarpic Neotropical tree. Heredity, 81, 134-143.

MARShALl, D. L. AND FOLSOM, M. W. 1991. Mate choice in plants: an anatomical to population perspective. Ann. Rev. Ecol. Syst., 22, 37-63.

MURAWSKI, D. A. AND HAMRICK, J. L. 1991. The effect of the density of flowering individuals on the mating systems of nine tropical tree species. Heredity, 67, 167-174.

MURAWSKI, D. A. AND HAMRICK, J. L. 1992. Mating system and phenology of Ceiba pentandra (Bombacaceae) in Central Panama. J. Hered., 83, 401-404.

MURAWSKI, D. A., DAYANANDAN, B. AND BAWA, K. S. 1994. Outcrossing rate of two endemic Shorea species from Sri Lankan tropical rain forest. Biotropica, 26, 23-29.

NASON, J. D., HERRE, E. A. AND HAMRICK, J. L. 1998. The breeding structure of a tropical keystone plant resource. Nature, 391, 685-687.

O'MALlEY, D. M. AND BAWA, K. S. 1987. Mating system of a tropical rain forest tree species. Am. J. Bot., 74, 1143-1149.

O'MALley, D. M., BUCKLEY, D. P., PRANCE, G. T. AND BAWA, K. S. 1988. Genetics of Brazil nut (Bertholletia excelsa Humb. \& Bonpl. Lecythidaceae), 2. Mating system. Theor. Appl. Genet., 76, 929-932. 
OLIVEIRA, P. E. AND SILVA, J. C. S. 1993. Reproductive biology of two species of Kielmeyera (Guttiferae) in the cerrados of Central Brazil. J. Trop. Ecol., 9, 67-79.

RATter, J. A., RIBEIRo, J. F. AND BRIDGEWATER, S. 1997. The Brazilian cerrado vegetation and threats to its biodiversity. Ann. Bot., 80, 223-230.

RAYMOND, M. AND ROUSSET, F. 1995. GENEPOP (version 1.2.): population genetics software for exact tests and ecumenism. J. Hered., 86, 248-249.

RHOADS, D. D. AND ROUFA, D. J. 1990. SEQAID II 3.80. Molecular Genetics Laboratory, Kansas State University, Manhattan.

RITLAND, K. 1985. The genetic mating structure of subdivided populations. I. Open mating model. Theor. Pop. Biol., 27, 51-74.
RITLAND, K. 1988. The genetic mating structure of subdivided populations. II. Correlated mating models. Theor. Pop. Biol., 34, 320-346.

RITLAND, K. 1989. Correlated matings in the partial selfer Mimulus guttatus. Evolution, 43, 848-859.

RITLAND, K. 1996. Multilocus mating system program - MLTR. Available free of charge via ftp at 128.100.165.100.

RITLAND, K. AND JAIN, S. 1981. A model for the estimation of outcrossing rate and gene frequencies using $n$ independent loci. Heredity, 47, 35-52.

SHAANKER, R. U., GANESHAIAH, K. N. AND BAWA, K. S. 1988. Parent-offspring conflict, sibling rivalry, and brood size patterns in plants. Ann. Rev. Ecol. Syst., 19, 177-205.

WRIGHT, s. 1940. Breeding structure of populations in relation to speciation. Am. Nat., 74, 232-248. 